\title{
A Comparative Evaluation of Three Commercially Available Dentin Desensitizers on the Shear Bond Strength of Composite Resins: An in vitro Study
}

\author{
${ }^{1}$ Shruti Patil, ${ }^{2}$ Balaram Naik, ${ }^{3}$ Prajna Shetty
}

\begin{abstract}
Background: The dentin desensitizers available for in-office application for prevention and/or treatment of post restorative dentinal hypersensitivity, act by blocking the open dentinal tubules. In doing so, they may influence the bond strength of the restorative resins. Thus, the aim of the study was to evaluate the effect of desensitizers on the shear bond strength of dentin adhesives and to check the extent of dentinal tubule occlusion caused by these desensitizers.
\end{abstract}

Materials and methods: Sixty-four premolars were randomly divided into four groups of sixteen each. The middle depth dentin was exposed by on the buccal surface and was etched using $37 \%$ phosphoric acid and rinsed. They were assigned to, Group 1: Gluma desensitizer, Group 2: VivaSens desensitizer, Group 3: Gluma Comfort Bond and desensitizer, and Group 4:Adper Single Bond 2. Composite resin post of $2 \mathrm{~mm}$ in height and width were built on these specimens. The samples were then mounted in acrylic resin blocks. Universal testing machine was used to test the shear bond strength. The data were analyzed using one-way analysis of variance (ANOVA) and post hoc Tukey's test.

Results: The mean values of the shear bond strength were for: Group1-18.61 $1.03 \mathrm{MPa}$, Group2-17.53 $\pm 1.36 \mathrm{MPa}$, Group3$22.63 \pm 1.61 \mathrm{MPa}$ and Group 4-23.12 $\pm 1.02 \mathrm{MPa}$. There was a statistically significant difference $(p<0.05)$ among the groups.

Conclusion: The use of dentin desensitizers' influences bond strength between the tooth and the adhesive. Among the various agents, the single bottle system containing Gluma comfort bond and desensitizer had the best adhesion among the desensitizer groups.

Keywords: Adper Single Bond 2, Dentin desensitizers, Gluma comfort bond, Gluma comfort bond and desensitizer, Adhesive resins, Shear bond strength, Vivasens.

How to cite this article: Patil S, Naik B, Shetty P. A Comparative Evaluation of Three Commercially Available Dentin Desensitizers on the Shear Bond Strength of Composite Resins: An in vitro Study. J Contemp Dent 2015;5(2):65-68.

\section{Source of support: Nil}

Conflict of interest: None

\footnotetext{
${ }^{1}$ Associate Professor, ${ }^{2}$ Professor, ${ }^{3}$ Graduate Student

${ }^{1-3}$ Department of Conservative Dentistry and Endodontics SDM Dental College, Dharwad, Karnataka, India
}

Corresponding Author: Shruti Patil, Associate Professor Department of Conservative Dentistry and Endodontics, SDM Dental College, Dharwad, Karnataka, India, Phone: 08362468142 e-mail: shruti78patil@gmail.com

\section{INTRODUCTION}

Postrestorative dentinal hypersensitivity is a common occurrence and happens due to the exposure of the dentinal tubules. ${ }^{1-5}$ The movement of the dentinal fluid in these exposed tubules, excite the pulpal nerves resulting the perceived sensation. ${ }^{1,2}$

The use of dentin desensitizers has been one of the most common approaches for management of postrestorative dentin hypersensitivity. Dentin desensitizers are applied to the tooth surface after etching and prior to the application of the bonding agent. The dentin desensitizers block the dentinal tubules and bring about a reduction in hypersensitivity. ${ }^{6-9}$

The most commonly used desensitizers are resin based. These agents block the tubules, either by precipitation of water insoluble substances, such as fluorides or by precipitation of plasma proteins in the substance of the tubules respectively. ${ }^{3,8-11}$

The blocking of the dentinal tubules by the desensitizer or the presence of certain components of the desensitizers may impede the permeability of the tubule ${ }^{9-13}$ and interfere with interaction between the dentin and adhesive restorative resin or the adhesive bonding agent which is paramount to ensure the long-term success of the resin restoration. ${ }^{79-14}$ This study was conducted to evaluate the effect of application of commercially available dentin desensitizers on the shear bond strength of the adhesives and compare the differences between them.

\section{MATERIALS AND METHODS}

A total of 64 freshly extracted human premolar teeth were taken and were randomly divided into four groups of 16 samples each. The labial surface of each tooth was ground under running water to expose middle depth dentin and the specimens were treated with $35 \%$ phosphoric acid for 15 seconds and thoroughly rinsed with water for the same amount of time with water spray.

The sample teeth were assigned to the following product (Table 1) groups:

- Groups: Per group $(\mathrm{n}=16)$

- Group 1: Gluma desensitizer, Heraeus Kulzer, GmBH, Hanau, Germany 
Table 1: List of products used in the study

\begin{tabular}{|c|c|c|c|c|}
\hline Groups & Products & Manufacturers & Composition & Application \\
\hline 1 & Gluma desensitizer (GD) & $\begin{array}{l}\text { Heraeus Kulzer, GmBH, } \\
\text { Dormagen, Germany }\end{array}$ & $5 \%$ glutaraldehyde, $35 \%$ HEMA & $\begin{array}{l}\text { GD application followed by } \\
\text { bonding with Adper Single Bond } 2\end{array}$ \\
\hline 2 & VivaSens desensitizer & $\begin{array}{l}\text { Ivoclar Vivadent, } \\
\text { Schaan, Liechtenstein }\end{array}$ & $\begin{array}{l}\text { Ethanol, water and hydroxypropyl } \\
\text { cellulose. Containing potassium } \\
\text { fluoride, polyethylene glycol } \\
\text { dimethacrylate and other } \\
\text { methacrylate }\end{array}$ & $\begin{array}{l}\text { VivaSense application followed by } \\
\text { Adper Single Bond } 2\end{array}$ \\
\hline 3 & $\begin{array}{l}\text { Gluma comfort bond+ } \\
\text { desensitizer (GCBD) }\end{array}$ & $\begin{array}{l}\text { Heraeus Kulzer, GmBH, } \\
\text { Dormagen, Germany }\end{array}$ & $\begin{array}{l}5 \% \text { glutaraldehyde, } 35 \% \text { hydroxyl } \\
\text { ethyl methacrylate, urethane } \\
\text { dimethacrylate, } 4 \text {-methoxyethyl } \\
\text { tetraacetate, methacrylate, } \\
\text { polyacrylic acid) }\end{array}$ & GCBD only \\
\hline 4 & Adper Single Bond 2 & $\begin{array}{l}\text { 3M ESPE, St Paul, } \\
\text { MN, USA }\end{array}$ & $\begin{array}{l}\text { Water, ethanol, HEMA, Bis- } \\
\text { GMA, dimethacrylates, initiators, } \\
\text { methacrylate functional copolymer } \\
\text { of polyacrylic and polyitaconic } \\
\text { acids and silica nanofillers }\end{array}$ & Adper Single Bond 2 only \\
\hline
\end{tabular}

- Group 2: VivaSens desensitizer, Ivoclar Vivadent, Schaan, Liechtenstein

- Group 3: Gluma Comfort Bond and Desensitizer Heraeus Kulzer GmBH, Hanau, Germany

- Group 4: Adper Single Bond 2, 3M ESPE, St Paul, MN, USA

Application of the respective agents:

- Group 1: Gluma desensitizer was applied with applicator tip over the dentin surface following which bonding agent (Adper S2) was applied and cured as per manufacturers' instructions.

- Group 2: VivaSens desensitizer was applied with applicator tip over the dentin surface following which bonding agent was applied similar to group 1 .

- Group 3: Gluma comfort bond and desensitizer was applied and cured.

- Group 4: The samples were treated with the application of the dentin-bonding agent, alone which served as controls.

Composite resin posts of dimension $2 \mathrm{~mm}$ in height and width were then built on the treated surfaces and the specimens were stored in artificial saliva for 48 hours and prior to testing were mounted on cold cure acrylic resin stubs.

Universal testing machine (Instron) was used to apply the shear load until specimen failure occurred at a crosshead speed of $0.5 \mathrm{~mm}$ per minute. Maximum load applied and failure load was recorded for each specimen and the shear bond strength was calculated. The values obtained in Newtons $(\mathrm{N})$ were converted to megapascals ( $\mathrm{MPa})$.

The data collected was analyzed statistically using ANOVA and Tukey's post hoc test (SPSS 16).

\section{RESULTS}

The mean force needed to debond the attachment between the specimen and the composite was the highest for group 4 (control group) at $23.12 \pm 1.02 \mathrm{MPa}$, followed by group 3 (Gluma and desensitizer) was at $22.64 \pm 1.61$ and group 1 (Gluma desensitizer) was at $18.61 \pm 1.03$ and the least was in group 2 (VivaSens) at $17.53 \pm 1.36 \mathrm{MPa}$. There was a statistically significant difference between all the four groups (Table 2).

When the pairwise comparison was done significant difference was found between then groups 1 and 3 and between groups 1 and 4 (Table 3).

Significant difference was also noted between groups 2 and 3 and between groups 2 and 4 . No statistically significant difference was noted between groups 3 and 4 .

\section{DISCUSSION}

Dentinal hypersensitivity has been reported after placement of restorations and more so with composite resin restorations. Application of dentin desensitizers has

Table 2: Intra- and intergroup comparisons with ANOVA

\begin{tabular}{llllll}
\hline & & \multicolumn{2}{c}{ Source of variation } & \\
\cline { 3 - 4 } Groups & Mean \pm standard deviation & Between groups & Within groups & f-value & \\
\hline 1 & $18.61 \pm 1.03$ & 381.51 & 98.15 & \\
2 & $17.53 \pm 1.36$ & & & \\
3 & $22.64 \pm 1.61$ & & & \\
4 & $23.12 \pm 1.02$ & & & \\
\hline${ }^{*} p<0.01$, highly significant [significant at $1 \%$ level of significance $\left.(p<0.01)\right]$ & & \\
\hline
\end{tabular}


Table 3: Pairwise comparison of four groups by Tukey's HSD post hoc test

\begin{tabular}{lllll}
\hline Groups & Group 1 & Group 2 & Group 3 & Group 4 \\
\hline Means & 18.61 & 17.53 & 22.63 & 23.12 \\
Group 1 & 1.00 & & & \\
Group 2 & 0.09 & 1.00 & & \\
Group 3 & 0.00 & 0.00 & 1.00 & \\
Group 4 & 0.00 & 0.00 & 0.71 & 1.00 \\
\hline *p<0.01, highly significant & & &
\end{tabular}

been one of the recommended modalities for treatment of the same. . $^{1-6}$

Studies have shown that application of dentin desensitizers has an influence on the bond strength between the tooth surface and the restoration. ${ }^{10-14}$ The present study evaluated the effect of application of dentin desensitizers on the shear bond strength and not micro-shear bond strength ( $\mu \mathrm{SBS})$ or microtensile bond strength $(\mu \mathrm{TBS})$ as $\mu \mathrm{TBS}$ and $\mu \mathrm{SBS}$ have shown higher pretest failures during sample preparation and over estimation of adhesion respectively. ${ }^{15-17}$

The highest bond strengths in the samples evaluated in the present study were for the adhesive only (control) group, followed by the single bottle Gluma and desensitizer followed by gluma desensitizer and then VivaSens.

The highest shear bond strength was observed with the samples treated with only the bonding agent; this is because a standard bonding procedure was employed for the specimens without any intervening desensitizer. Adper Single Bond 2 being a total-etch adhesive, contains the moisture-tolerant Vitrebond copolymer in a water/ ethanol solvent this aids in adhesion between the bonding agent and the dentin surface, and thus the monomer of the adhesive flows into the dentinal tubules and achieves better adhesion. ${ }^{16-18}$

The application of a desensitizer between the bonding agent and the dentin surface may interfere with the flow of the adhesive and that's the reason for lesser bond strengths observed.

The Gluma containing agents showed better bond strengths ${ }^{10}$ as compared to VivaSense. The better bond strength of the Gluma based agents is due to the glutaral dehyde in Gluma which may bond to collagen fibrils of dentin and stabilize the network for resin infiltration, it is also shown to coagulate the proteins of the dentinal fluid and plugs the tubules. ${ }^{719-22}$ But as it is non-polymerizable it is not capable of forming a bond with the resin, and thus it has shown to reduce the bond strength of resin cements. ${ }^{7,23,24}$ However, there are reports which show that Gluma desensitizer did not affect the bond strength of any of the three adhesive systems tested ${ }^{8,13}$ and in a study ${ }^{10}$ the samples treated with Gluma desensitizer had better bond strength when compared to other desensitizers.

The present study also included a group wherein the desensitizer and the bonding agent were in a single bottle and found that the bond strength was better in samples treated with single bottle system as compared to the twobottled system. This phenomenon can be attributed to the fact that as both the active agents are in the same bottle, and thus during application, the percentage of bonding agent occupying the etched surface may be higher than in the two bottled solutions, where in the desensitizer is completely layering the etched surface prior to the application of the bonding agent. ${ }^{16}$

The least bond strength was with VivaSense, this has been attributed to the fact that the phosphonic acid methacrylate modified polyacrylic acid in VivaSense forms Ca-salts that precipitates in the dentinal tubules. In addition, the potassium ions of its fluoride component support precipitation of the salts ${ }^{25,26}$ and the precipitation of microcrystals and mineral deposits into dentin tubules prevent resin infiltration. ${ }^{7,25}$ Hence, the reduced bond strength as shown in the study. ${ }^{7,26}$ However, a study conducted by Lehmann $\mathrm{N}$ et $\mathrm{al}^{10}$ showed VivaSens desensitizer did not alter the adherence of any of the bonding agents tested.

It can be stated that use of desensitizers showed decreased shear bond strength values as compared to application of the adhesive alone. The Gluma containing desensitizers have better bond strengths than VivaSens. Among the Gluma containing agents, the single bottle system GCBD has better strength as compared to the two-bottled system of GCB and GD.

\section{CLINICAL SIGNIFICANCE}

The use of dentin desensitizers reduces the adhesive bond strength between the restorative resin and the tooth surface. In scenarios necessitating the use of dentin desensitizers, it is better to use a single bottle containing the desensitizer as well as the bonding agent.

\section{REFERENCES}

1. Auschill TM, Koch CA, Wolkewitz M, Hellwig E, Arweiler NB. Occurrence and causing stimuli of postoperative sensitivity in composite restorations. Oper Dent 2009;34:3-10.

2. Akpata ES, Behbehani J. Effect of bonding systems on postoperative sensitivity from posterior composites. Am J Dent 2006;19:151-154.

3. Bartold PM. Dentinal hypersensitivity: a review. Aust Dent J 2006;51:212-218.

4. Jacobsen PL, Bruce G. Clinical dentin hypersensitivity: understanding the causes and prescribing a treatment. J Contemp Dent Pract 2001;2:1-12.

5. Pashley DH, Carvalho RM, Pereira JC, et al. The use of oxalate to reduce dentin permeability under adhesive restorations. Am J Dent 2001;14:89-94. 
6. Pashley DH. Potential treatment modalities for dentin hypersensitivity: in-office products. In: Addy M, Embery G, Edgar WM, Orchardson R, editors. Tooth wear and sensitivity: clinical advances in restorative dentistry. London: Martin Dunitz 2000:351-365.

7. Huh JB, Kim JH, Chung MK, Lee HY, Choi YG, Shim JS. The effect of several dentin desensitizers on shear bond strength of adhesive resin luting cement using self-etching primer. J Dent 2008;36:1025-1032.

8. Schupbach P, Lutz F, Finger WJ. Closing of dentinal tubules by Gluma desensitizers. Eur J Oral Sci 1997;105:414-421.

9. Kolker JL, Vargas MA, Armstrong SR, Dawson DV. Effect of desensitizing agents on dentin permeability and dentin tubule occlusion. J Adhes Dent 2002;4:211-221.

10. Kulunk S, Sarac D, Kulunk D, Karakas O. The effects of different de sensitizing agents on the shear bond strength of adhesive resin cement to dentin. J Esthet Resto Dent 2011 Dec;23(6):380-387.

11. Awang RAR, Masudi SM, MohdNor WZW. Effect of desensitizing agent on shear bond strength of an adhesive system. Arch Orofac Sci 2007;2:32-35.

12. Van Meerbeek B, Lambrechts P, Inokoshi S, Braem M, Vanherle G. Factors affecting adhesion to mineralized tissues. Oper Dent 1992;Suppl 5:111-124.

13. Soeno K, Taira Y, Matsumura H, Atsuta M. Effects of desensitizers on bond strength of adhesive luting agents to dentin. J Oral Rehab 2001;28:1122-1128.

14. Al Qahtani MQ, Platt JA, Moore BK, Cochran MA. The effect on shear bond strength of rewetting dry dentin with two desensitizers. Oper Dent 2003;28:287-296.

15. Cardoso P EC, Braga R, Carrilho M. Evaluation of microtensile, shear and tensile tests determining the bond strength of three adhesive systems. Dent Mater 1998;14:394-398.

16. Itota T, Torii Y, Nakabo S, Yoshiyama M. Effect of fluoride application on tensile bond strength of self-etching adhesive systems to demineralized dentin. J Prosthet Dent 2002;88:503-510.
17. Armstrong S, Geraldeli S, Maia R, Raposo LH, Soares CJ, Yamagawa J. Adhesion to tooth structure: a critical review of micro bond strength test methods. Dent Mater 2010 Feb;26(2): e50-62.

18. Gillam DG, Khan N, Mordan NJ, Barber PM. Scanning electron microscopy (SEM) investigation of selected desensitizing agents in the dentin disc model. Endod Dent Traumatol 1999;15:198-204.

19. Assis CA, Antoniazzi RR, Zanatta FB, Rosing CR. Efficacy of gluma desensitizer on dentin hypersensitivity in periodontally treated patients. Braz Oral Res 2006;20:252-256.

20. Lehmann N, Degrange M. Effect of four desensitizer on the shear bond strength of three bonding systems. Eur Cells Mat 2005;9(1):52-53.

21. Ritter AV, Bertoli C, Swift EJ. Dentin bond strengths as a function of solvent and gluteraldehyde content. Am J Dent 2001;14:221-226.

22. Walter R, Miguez PA, Swift EJ Pereira PNR. Long-term bond strengths to dentin treated with different re-wetting solutions. Am J Dent 2008;21:143-147.

23. Qin $\mathrm{C}, \mathrm{Xu} \mathrm{J}$, Zhang Y. Spectroscopic investigation of the function of aqueous 2-hydroxyethylmethacrylate/glutaraldehyde solution as a dentin desensitizer. Eur J Oral Sci 2006;114: 354-359.

24. Soares CJ, Santos-Filho PC, Barreto BC, da Mota AS. Effect of previous desensitizer and rewetting agent application on shear bond strength of bonding systems to dentin. Cienc Odontol Bras 2006;9(4):6-11.

25. Akca T, Yazici AR, Celik C, Ozgunaltay G, Dayangac B. The effect of desensitizing treatments on the bond strength of resin composite to dentin mediated by a Self-etching Primer. Oper Dent 2007;32(5):451-56.

26. Ravikumar N, Shankar P, Indira R. Shear bond strengths of two dentin bonding agents with two desensitizers: An in vitro study. Journal of Conservative Dentistry 2011;14(3): 247-251. 